\title{
The Effect of Herbal Extract Mixture (Digestarom) Supplementation to Diets on Duodenum and Ileum Histology in Broiler Chickens
}

\author{
Özay GÜLEŞ ${ }^{*}$, Mustafa YILDIZ² \\ 'Afyon Kocatepe University, Faculty of Veterinary Medicine, Department of Histology and Embryology, 03200, Afyon, Turkey \\ ${ }^{2}$ Department of Occupational Health and Safety, Can School of Applied Sciences, Canakkale Onsekiz Mart University, Canakeale, Turkey
}

\begin{abstract}
Phytogenic feed additives are used as antibacterial, anti-inflammatory and performance enhancer in the nutrition of broiler chicks. In the present study, it was aimed to investigate the effects of the usage of phytogenic feed additives which are used as an alternative to antibiotics in broilers at different levels in the rations, on the morphology of the duodenum and ileum. For this purpose, 48 male ROSS-308 one-day-old broiler chicks were used in the study. Chicks with a body weight of $43 \pm 3 \mathrm{~g}$ were randomly divided into 24 replicate sets from three experimental groups, each of which consisted of 8 replicates ( 2 chicks per house). The other two experimental groups were fed with a basal diet supplemented with $100 \mathrm{mg} / \mathrm{kg}$ (DIG100) and $150 \mathrm{mg} / \mathrm{kg}$ (DIG150) phytogenic product Digestarom ${ }^{\circledR}$. In conclusion, it was determined that herbal extract mixture supplementation to broiler chick rations generally increased villus height and villus width, and decreased tunica muscularis thickness. Hence, herbal extract mixture might lead to better digestion and absorption by increasing the intestinal surface area, digestion and absorption levels, also increase body weight gain in broiler chicks by reducing the microbial load. Keywords: Broiler, crypt depth, muscular thickness, villus height, villus width
\end{abstract}

\section{Etlik Piliç Rasyonlarına Bitkisel Ekstrakt Karışımı (Digestarom) Eklenmesinin Duodenum Ve İleum Histolojisi Üzerine Etkisi}

ÖZ

Etlik piliç beslemede fitojenik yem katkıları antibakteriyel, antienflamatuvar ve performans arttırıcı olarak kullanılmaktadır. Sunulan çalışmada broylerlerde antibiyotiklerin yerine alternatif olarak kullanılan fitojenik yem katkı maddelerinin rasyonlarda farklı düzeyde kullanılmasının, duodenum ve ileum morfolojisi üzerine etkilerinin araştırılması amaçlanmıştır. Bu amaçla çalışmada 48 adet erkek ROSS-308 bir günlük broyler civciv kullanıldı. Vücut ağırlıkları $43 \pm 3$ g olan civcivler, her bir deney grubu 8 tekrardan oluşan (her kümeste 2 civciv olmak üzere) üç deney grubundan 24 tekrarlama kümesine rastgele ayrıldı. Kontrol grubu hayvanlar misır/soya fasulyesi küspesine dayalı bazal diyet ile beslendi. Diğer iki deneme grubu ise $100 \mathrm{mg} / \mathrm{kg}$ (DIG100) ve $150 \mathrm{mg} / \mathrm{kg}$ (DIG150) fitojenik ürün Digestarom ${ }^{\circledR}$ ile desteklenmiş bazal diyetle beslendi. Sonuç olarak, broyler civciv rasyonlarına bitkisel ekstrakt karışımı takviyesinin genel olarak villus yüksekliği ve villus genişliğini artırdığı, tunika muskularis kalınlığını ise azalttığı belirlenmiştir. Dolayısıyla, bitkisel ekstrakt karışımı bağırsak yüzey alanını, sindirim ve emilim seviyelerini artırarak daha iyi sindirim ve absorbsiyona yol açabilir, ayrıca mikrobiyal yükü azaltarak broyler civcivlerde canlı ağıllk kazancını artırabilir.

Anahtar Kelimeler: Broiler, kas kalınlığı, kript derinliği, villus genişliği, villus yüksekliği

To cite this article: Özay G. Yuldiz M. The Effect of Herbal Extract Mixture (Digestarom) Supplementation to Diets on Duodenum and Ileum Histology in Broiler Chickens. Kocatepe Vet J. (2021) 14(4):399-407

Submission: 30.06.2021 Accepted: 18.10.2021 Published Online: 02.11.2021

ORCID ID; GÖ: 0000-0001-6170-1706, MY: 0000-0003-4128-8947

*Corresponding author e-mail: ogules@aku.edu.tr 


\section{INTRODUCTION}

The additives such as antibiotics, probiotics, prebiotics, organic acids, herbal extracts and enzymes are added to feedstuffs in order to improve the health level and feed efficiency of animals and to improve nutrient utilization (Yörük et al. 2004). The usage of growth-stimulating antibiotics [antibiotic growth promoters (AGPs)] in the poultry industry has been severely criticized by governments and consumers due to the development of bacterial resistance and the harmful effects of these products on human health (Alçiçek et al. 2004). Therefore, the usage of antibiotics as growth stimulators in animal nutrition has been completely banned in the member states of the European Union in 2006 (Vesna et al. 2007). As a result of this situation, feed additive manufacturers have directed to the search for products that may be an alternative to antibiotics. Plant extracts have an important place among the feed additives. The positive effects of plant extracts on animal yield and health have been determined by studies (Du ve $\mathrm{Hu}$ 2004, Guynot et al. 2005, Cherian et al. 2013, Zeng et al. 2015, Du et al. 2016, Hafeez et al. 2016). One of the most important features of plant extracts is that they are natural. Due to this feature, their usage in animal nutrition has increased in recent years.

Phytogenic feed additives (PFAs) are plant extracts obtained from various aromatic herbs and spices. As phytogenic feed additives, the whole plant, the seed, fruit, leaf and root parts of the plant also essential oils are used (Çetin and Göçmen 2013). Many different bioactive elements such as alkaloids, flavonoids, mucilage, glycosides, saponins, phenolics, piperine, polyphenols, polypeptide, tannins, terpenoids, cineol, allicin, linalool, capsaicin and thymol can be found in their structures (Upadhaya ve Kim 2017). Phytogenic feed additives have antibacterial, anti-inflammatory, antiviral (Du et al. 2016), antifungal (Guynot et al. 2005), anticoccidial (Du and $\mathrm{Hu} 2004$ ), antioxidant (Cherian et al. 2013), appetite enhancer, digestive facilitator effects (Hafeez et al. 2016, Erhan 2015). Because of these features, their usage in the feeding of broiler chickens has come into prominence. Also, these substances increase small intestinal villus heights and crypt depths, as well as provide significant increases in the absorption surface (Zeng et al. 2015).

Despite these positive effects of phytogenic feed additives, some studies in broilers did not show any effect in terms of performance, feed consumption, feed conversion rate and small intestine morphology. Lee et al. (2003) found that the additions of thymol essential oil in thyme and cinnamaldehyde essential oil in cinnamon to broiler feeds did not have a positive effect on the growth performance of broiler chickens. Basmacioğlu et al. (2004) determined that the additions of oregano and rosemary essential oil and their mixtures to broiler feeds did not differ in terms of feed consumption and feed conversion ratio compared to control groups. In another study, Mountzouris et al. (2011) reported that the addition of an essential oil mixture containing carvacrol, anethole and limonene to broiler feeds did not show any difference in performance values compared to the control group at the end of the 42-day feeding period. In studies conducted to evaluate the intestinal morphology, it was found that the additions of clove (Agostini et al. 2012) and oregano essential oil to broiler feeds (Peng et al. 2016) did not have an effect on the villus morphology parameters of broiler chickens. In studies investigating the effects of phytogenic feed additives on growth performance, feed consumption and intestinal morphology, it has been determined that the reasons for not showing positive results may be the type or dosage of phytogenic feed additives, diseases and/or stress factors such as ambient temperature and feeding condition (Basmacioğlu et al. 2004, Lee et al. 2003, Hong et al. 2012).

The small intestine is an organ that the digestion and absorption of foods take place. To be long of the small intestine provides long-term contact both between foods and digestive enzymes and between digested foods and the absorptive cells of the epithelium. The small intestine consists of three parts as duodenum, jejunum and ileum. Many features of these sections are the same. The inner surface of the small intestine macroscopically shows numerous folds called plica circularis (plicae circulares). When examined microscopically, intestinal villi are seen. These structures are protrusions of the mucosa towards the lumen. Intestinal villi consist of lamina epithelialis and lamina propria. Thanks to these formations, which are only found in the small intestine sections, the absorption surface increases considerably. The lamina epithelialis consists of a single layer of high columnar cells (absorptive cells) and goblet cells between them. The number of goblet cells increases from the duodenum towards the ileum. The main function of these cells is to secrete acid glycoproteins, which are to protect and lubricate the intestinal surface from both chemical and mechanical effects. Among the intestinal villi, there are small openings of simple tubular glands called intestinal glands (crypts or Lieberkühn glands). The epithelium of the villi continues with the epithelium of the glands. Intestinal glands contain undifferentiated cells, absorptive cells, goblet cells, Paneth cells, and enteroendocrine cells. Undifferentiated cells in the crypts differentiate into mucus-secreting goblet cells of the villi epithelium and cylindrical absorptive cells (Tanyolaç 1999, Junqueira et al. 2006).

In this study, it was aimed to investigate the effects of phytogenic feed additives at different levels in rations, which are used as an alternative to antibiotics in broilers, on duodenum and ileum morphologies. 


\section{MATERIAL and METHODS}

Before starting the presented study, a permit was obtained from the Ethics Committee of Aydin Adnan Menderes University (Aydin, Turkey). In this study, 48 male ROSS-308 one-day-old broiler chicks were used. The animals were obtained from a local commercial hatchery located near Aydin. The experimental area was cleaned and fumigated one week before the experiment, then heated to $32{ }^{\circ} \mathrm{C}$. The study continued for 42 days. The animals were kept in 24 hours of light and $50-60 \%$ relative humidity during the experimental period. The ambient temperature was $32{ }^{\circ} \mathrm{C}$ in the first week. Then, it was set to a constant temperature of $24^{\circ} \mathrm{C}$ by lowering $0.5^{\circ} \mathrm{C}$ per day. Feed and water were given as ad libitum.

Average weight of a chick ranged between 40 to $46 \mathrm{~g}$ $(43 \pm 3 \mathrm{~g})$. Chicks were randomly placed in 24 replicate pens of three experimental groups (8 replicate pens per treatment; 2 chicks in per pen). Control animals were fed a corn/soybean meal-based basal diet (Aviagen 2014). Basal diets were formulated in three different ways, as indicated by Aviagen (2014), starter (days 1-10), grower (days 11-24) and finisher (days 2542). The other two experimental groups were fed a basal diet supplemented with $100 \mathrm{mg} / \mathrm{kg}$ (DIG100) and $150 \mathrm{mg} / \mathrm{kg}$ (DIG150) phytogenic product Digestarom ${ }^{\circledR}$ (BIOMIN Holding GmbH, Getzersdorf, Austria). Each $\mathrm{kg}$ of Digestarom ${ }^{\circledR}$ contains $20 \mathrm{~g}$ of cinnamon, $20 \mathrm{~g}$ of cumin, $170 \mathrm{~g}$ of peppermint oil, $150 \mathrm{~g}$ of garlic oil, $50 \mathrm{~g}$ of anise oil, 40 $\mathrm{g}$ of fennel oil also $\mathrm{SiO} 2$ and $\mathrm{NaCl}$ as carriers.

On the 21st and 42nd days of the study, one animal randomly selected from the eight replicate groups in each experimental group was slaughtered. Duodenum and ileum tissue samples from each animal were removed and fixed in neutral buffered formalin (NBF) solution for 24 hours. After routine histological processing, the tissue samples were embedded in paraffin and $6 \mu \mathrm{m}$-thick serial sections were taken from the prepared paraffin blocks at 300 $\mu \mathrm{m}$ intervals.

Crossmon's triple staining method (Crossmon 1937) was applied to determine the histological appearance and histomorphological changes in three serial sections. Periodic Acid Schiff Reagent (PAS) staining method (Culling et al. 1985) was applied to the other three sections to reveal the number of goblets. The prepared preparations were examined under a light microscope (Olympus CX41, Japan). Five in each section, a total of 15 villus height, villus width, crypt depth and muscular layer thickness for each animal, interactively with the help of image analysis program (Olympus cellSens Entry, Imaging software, Olympus Corporation, Tokyo 163-0914, Japan) were determined. In addition, goblet cell numbers in the middle $100 \mu \mathrm{m}$ portion of 15 villi belong to each animal were counted manually.

\section{Statistical Analysis}

SPSS (Statistical Package for the Social Sciences, version 18.0) package program was used for statistical analysis of the obtained data. The results were presented as mean \pm standard errors. The statistical differences between the groups in terms of villus height, villus width, crypt depth, muscular layer thickness and goblet cell number in tissue samples taken from the duodenum and ileum on the 21st and 42nd days of the study were evaluated with KruskalWallis analysis of variance. Post hoc 97 multiple comparison test was performed to determine which group or groups caused the difference. Values with differences $\mathrm{p}<0.05{ }^{(*)}, \mathrm{p}<0.01{ }^{(* *)}, \mathrm{p}<0.001{ }^{(* *)}$ were considered significant in the statistical analyzes (Conover 1980).

\section{RESULTS}

The villus height, villus width, crypt depth, tunica muscularis thickness and goblet cell number in duodenums of all groups are given in Table 1 and Table 2 .

On the 21st day of the study, in the histomorphological examination of samples taken from the duodenum, it was determined that the villus height significantly increased in the DIG100 group compared to the control group. There was no statistical difference between the control and DIG150 groups. In the evaluation made in terms of villus width, it was seen that the numerical increases in the DIG100 and DIG150 groups were not statistically significant compared to the control groups (Figure 1). The crypt depth was found as similar in all groups. Although the tunica muscularis thickness decreased in all digestrom-treated groups compared to the control groups, it was determined that this decrease was only statistically significant in the DIG100 group (Figure 2). It was also observed that there was no significant difference in terms of the number of goblet cells between all groups.

In the histomorphological examination of the samples taken from duodenum on the 42nd day of the study, it was determined that the increase in the DIG150 group was statistically significant, although the villus height increased in all digestrom-treated groups compared to control groups. In the evaluation made in terms of villus width, it was found that the increase in the DIG150 group was significant compared to control group. In addition, villus width significantly decreased in DIG100 group compared to control group (Figure 3). The crypt depth was similar in the control, DIG100 and DIG150 groups. There was no significant in terms of tunica muscularis thickness between groups. In addition, it was determined that the number of goblet cells in all groups given digestrom was significantly lower than control group.

In the histomorphological examination of ileum samples on the 21 st day of the study, it was 
determined that there was no statistically significant difference in terms of villus height between control, DIG100 and DIG150 groups. In the evaluation made in terms of villus width, it was determined that the increase in DIG100 and DIG150 groups was statistically significant compared to control group (Figure 4). The crypt depth was found to be similar in all groups. Tunica muscularis thickness significantly decreased in all digestrom-treated groups compared to control groups, while the difference between DIG100 and DIG150 groups was not significant. In addition, while the number of goblet cells was similar between control and DIG100 groups, the increase in the DIG150 group was statistically significant compared to other groups (Table 3).
On the 42nd day of the study, in the histomorphological examination of ileum samples, it was determined that the villus height in DIG100 and DIG150 groups significantly increased compared to control group. In addition, although the villus width in all digestrom groups increased compared to control groups, the increase in the DIG100 group was only statistically significant (Figure 5). In the evaluation made in terms of crypt depth, tunica muscularis thickness and number of goblet cells it was determined that the difference between the control and digestrom groups was not significant (Table 4).

Table 1. On the 21st day of the study, villus height, villus width, crypt depth, muscular thickness and number of goblet cells in the duodenums of control and digestrom-treated groups $(n=8)$.

\begin{tabular}{|c|c|c|c|c|c|}
\hline Groups & $\begin{array}{l}\text { Villus Height } \\
\begin{array}{c}(\mu \mathrm{m}) \\
(\bar{x} \pm S \mathrm{x})\end{array}\end{array}$ & $\begin{array}{c}\text { Villus Width } \\
\begin{array}{c}(\mu \mathrm{m}) \\
(\bar{x} \pm S \mathrm{x})\end{array}\end{array}$ & $\begin{array}{c}\text { Crypt Depth } \\
\begin{array}{c}(\mu \mathrm{m}) \\
(\bar{x} \pm S \mathrm{x})\end{array}\end{array}$ & $\begin{array}{c}\text { Muscular } \\
\text { Thickness } \\
(\mu \mathrm{m}) \\
(\bar{x} \pm S \mathrm{x})\end{array}$ & $\begin{array}{c}\begin{array}{c}\text { Number of } \\
\text { Goblet Cells }\end{array} \\
(\bar{x} \pm S x)\end{array}$ \\
\hline Control & $1154.76 \pm 36.13^{b}$ & $177.16 \pm 3.93$ & $131.34 \pm 3.09$ & $197.39 \pm 3.76^{a}$ & $7.14 \pm 0.16$ \\
\hline DIG100 & $1406.53 \pm 40.79^{a}$ & $179.30 \pm 3.68$ & $128.21 \pm 3.27$ & $183.52 \pm 3.22^{\mathrm{b}}$ & $7.31 \pm 0.15$ \\
\hline DIG150 & $1103.52 \pm 32.50^{\mathrm{b}}$ & $182.45 \pm 3.96$ & $127.39 \pm 3.15$ & $196.86 \pm 3.44^{a}$ & $7.26 \pm 0.18$ \\
\hline $\mathrm{p}$ & $* * *$ & NS & NS & $*$ & NS \\
\hline
\end{tabular}

Table 2. On the 42nd day of the study, villus height, villus width, crypt depth, muscular thickness and number of goblet cells in the duodenums of control and digestrom-treated groups ( $\mathrm{n}=8)$.

\begin{tabular}{|c|c|c|c|c|c|}
\hline Groups & $\begin{array}{c}\text { Villus Height } \\
\begin{array}{c}(\mu \mathrm{m}) \\
(\bar{x} \pm S \mathrm{x})\end{array}\end{array}$ & $\begin{array}{c}\text { Villus Width } \\
\begin{array}{c}(\mu \mathrm{m}) \\
(\bar{x} \pm S \mathrm{x})\end{array}\end{array}$ & $\begin{array}{c}\text { Crypt Depth } \\
(\mu \mathrm{m}) \\
(\mathrm{x} \pm \mathrm{Sx})\end{array}$ & $\begin{array}{c}\text { Muscular } \\
\text { Thickness } \\
(\mu \mathrm{m}) \\
(\overline{\mathrm{x}} \pm \mathrm{S} \overline{\mathrm{x}})\end{array}$ & $\begin{array}{c}\begin{array}{c}\text { Number of } \\
\text { Goblet Cells }\end{array} \\
(\bar{x} \pm S x)\end{array}$ \\
\hline Control & $974.17 \pm 44.77^{b}$ & $183.31 \pm 4.96^{b}$ & $167.08 \pm 5.06$ & $250.69 \pm 4.62$ & $7.97 \pm 0.19^{a}$ \\
\hline DIG100 & $1038.01 \pm 41.51^{\mathrm{b}}$ & $167.78 \pm 6.02^{c}$ & $172.71 \pm 4.99$ & $260.48 \pm 5.75$ & $6.71 \pm 0.18^{b}$ \\
\hline DIG150 & $1360.47 \pm 33.26^{a}$ & $199.53 \pm 4.72^{a}$ & $159.41 \pm 3.81$ & $248.41 \pm 5.02$ & $6.28 \pm 0.17^{b}$ \\
\hline $\mathrm{p}$ & *** & *** & NS & NS & *** \\
\hline
\end{tabular}



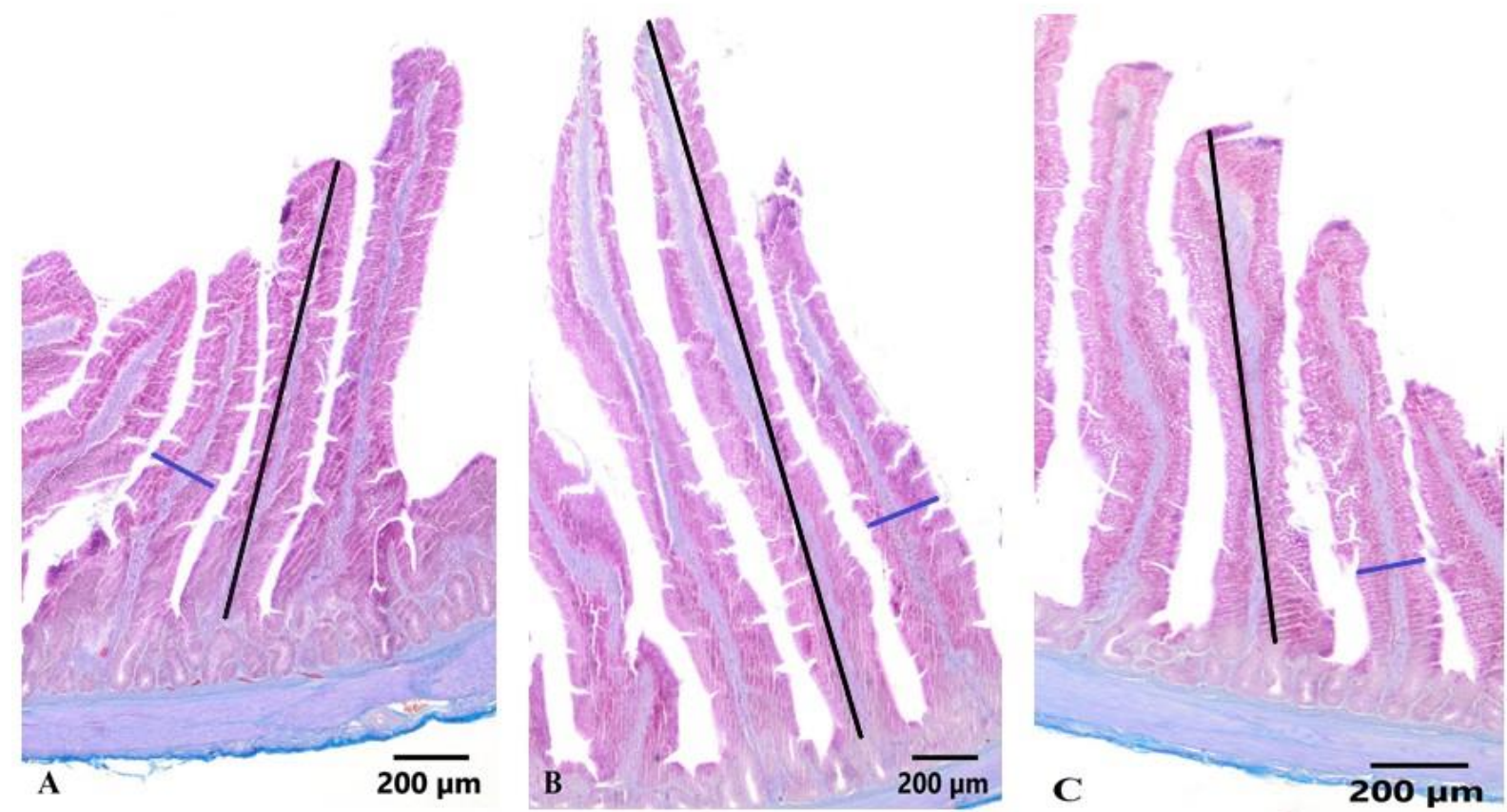

Figure 1: On the 21st day of the study, villus height (black lines) and villus width (blue lines) in the duodenums of control (A) and digestrom100 (B) and digestrom150 (C)-treated groups $(\mathrm{n}=8)$. Crossmon triple staining. Scale bar: $200 \mu \mathrm{m}$.
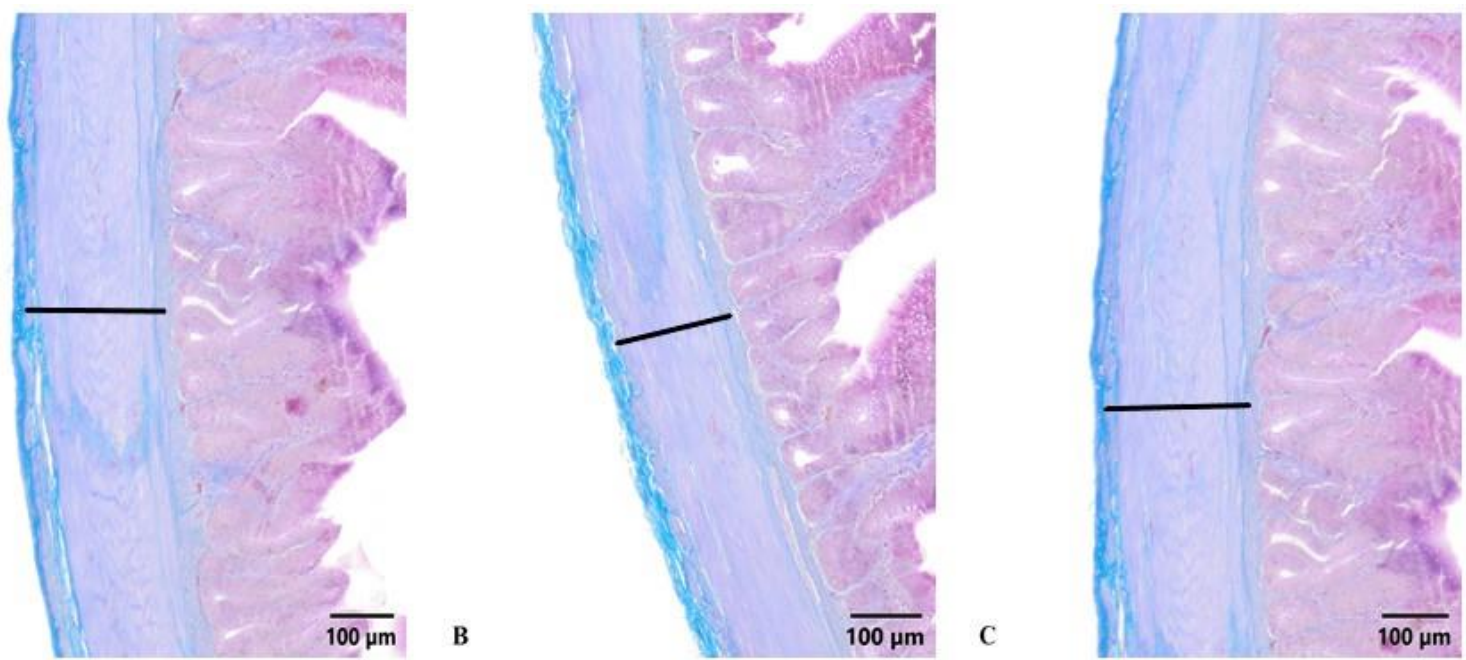

Figure 2: On the 21st day of the study, tunica muscularis thickness (black lines) in the duodenums of control (A) and digestrom100 (B) and digestrom150 (C)-treated groups ( $\mathrm{n}=8)$. Crossmon triple staining. Scale bar: $100 \mu \mathrm{m}$. 


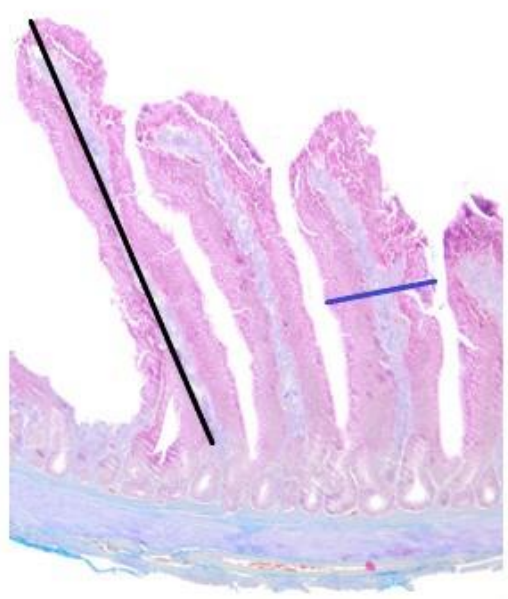

A

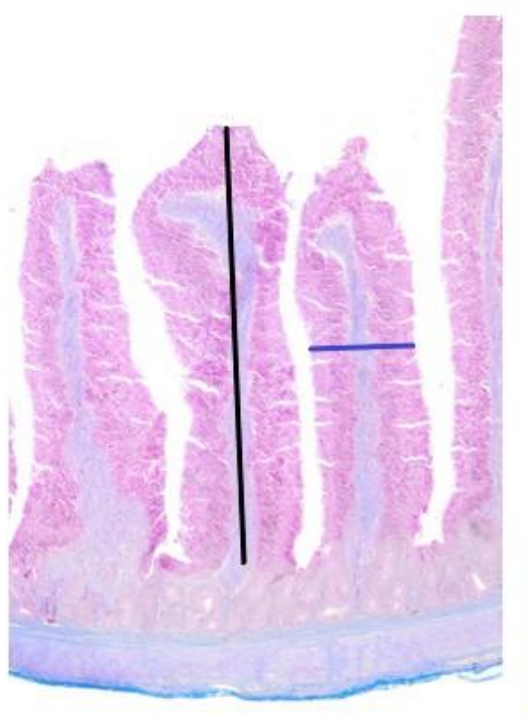

$200 \mu \mathrm{m}$

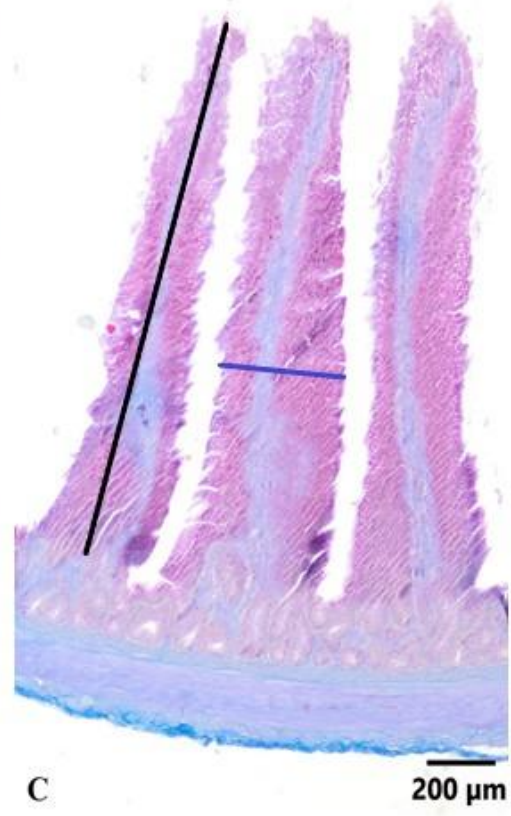

Figure 3: On the 42st day of the study, villus height (black lines) and villus width (blue lines) in the duodenums of control (A) and digestrom100 (B) and digestrom150 (C)-treated groups $(n=8)$. Crossmon triple staining. Scale bar: $200 \mu \mathrm{m}$.
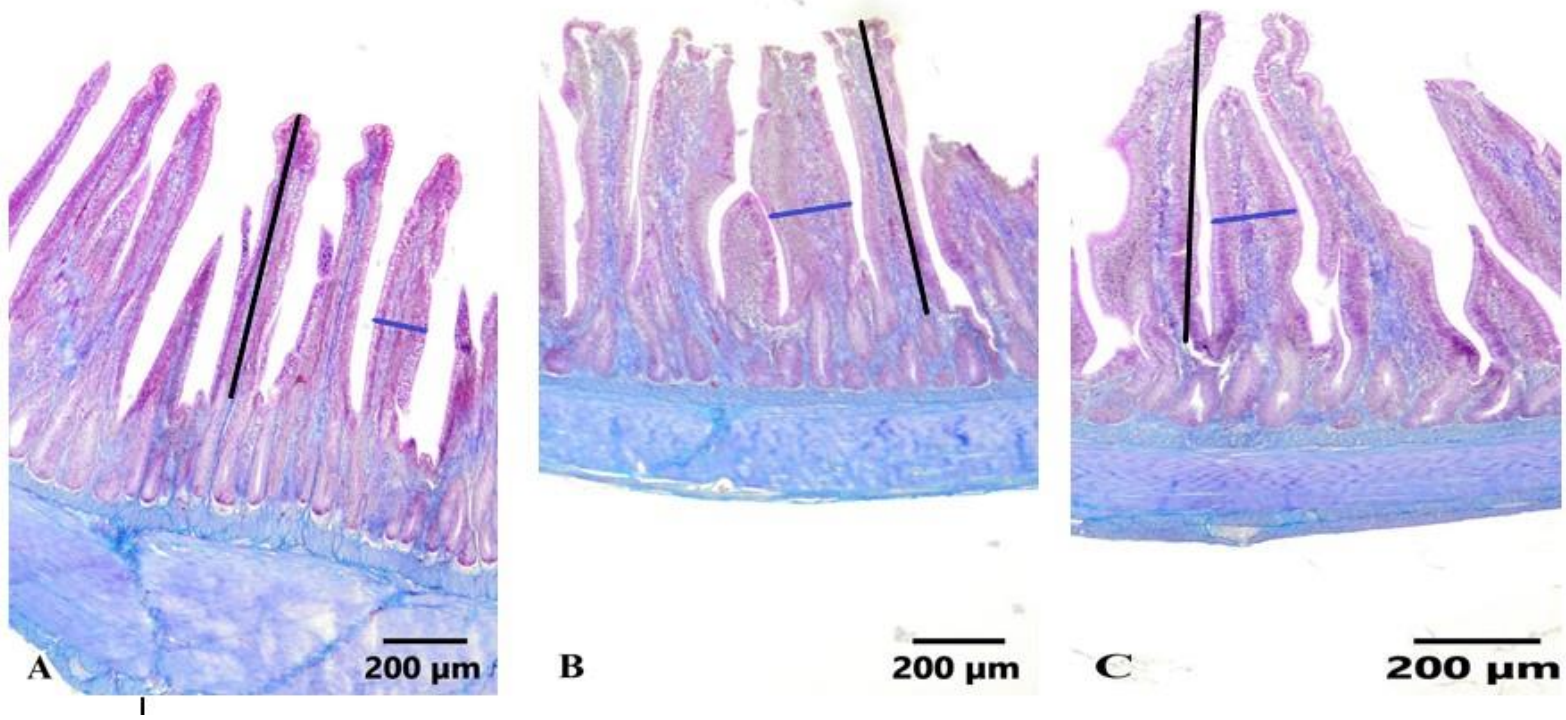

B
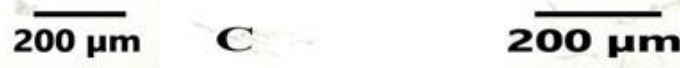

Figure 4: On the 21st day of the study, villus height (black lines) and villus width (blue lines) in the ileums of control (A) and digestrom100 (B) and digestrom150 (C)-treated groups $(n=8)$. Crossmon triple staining. Scale bar: $200 \mu \mathrm{m}$. 
Table 3. On the 21 st day of the study, villus height, villus width, crypt depth, tunica muscularis thickness and the number of goblet cells in the ileums of control and digestrom-treated groups ( $\mathrm{n}=8$ ).

\begin{tabular}{|c|c|c|c|c|c|}
\hline Groups & $\begin{array}{c}\text { Villus Height } \\
\begin{array}{c}(\mu \mathrm{m}) \\
(\bar{x} \pm S x)\end{array}\end{array}$ & $\begin{array}{c}\text { Villus Width } \\
\begin{array}{c}(\mu \mathrm{m}) \\
(\overline{\mathrm{x}} \pm \mathrm{S} \bar{x})\end{array}\end{array}$ & $\begin{array}{l}\text { Crypt Depth } \\
\begin{array}{c}(\mu \mathrm{m}) \\
(\bar{x} \pm S \mathrm{x})\end{array}\end{array}$ & $\begin{array}{c}\text { Muscular } \\
\text { Thickness } \\
(\mu \mathrm{m}) \\
(\bar{x} \pm S \mathrm{x})\end{array}$ & $\begin{array}{c}\begin{array}{c}\text { Number of } \\
\text { Goblet Cells }\end{array} \\
(\bar{x} \pm S \bar{x})\end{array}$ \\
\hline Control & $590.14 \pm 10.29$ & $176.98 \pm 4.74 b$ & $160.09 \pm 2.84$ & $248.89 \pm 5.44 a$ & $12.00 \pm 0.15^{b}$ \\
\hline DIG100 & $615.97 \pm 10.27$ & $191.25 \pm 3.89 a$ & $160.18 \pm 2.53$ & $226.89 \pm 4.05^{b}$ & $11.76 \pm 0.15^{b}$ \\
\hline DIG150 & $615.76 \pm 11.50$ & $187.69 \pm 3.65^{\mathrm{a}}$ & $155.24 \pm 2.66$ & $220.93 \pm 4.95^{b}$ & $12.50 \pm 0.16^{\mathrm{a}}$ \\
\hline $\mathrm{p}$ & NS & ** & NS & *** & $* * *$ \\
\hline
\end{tabular}
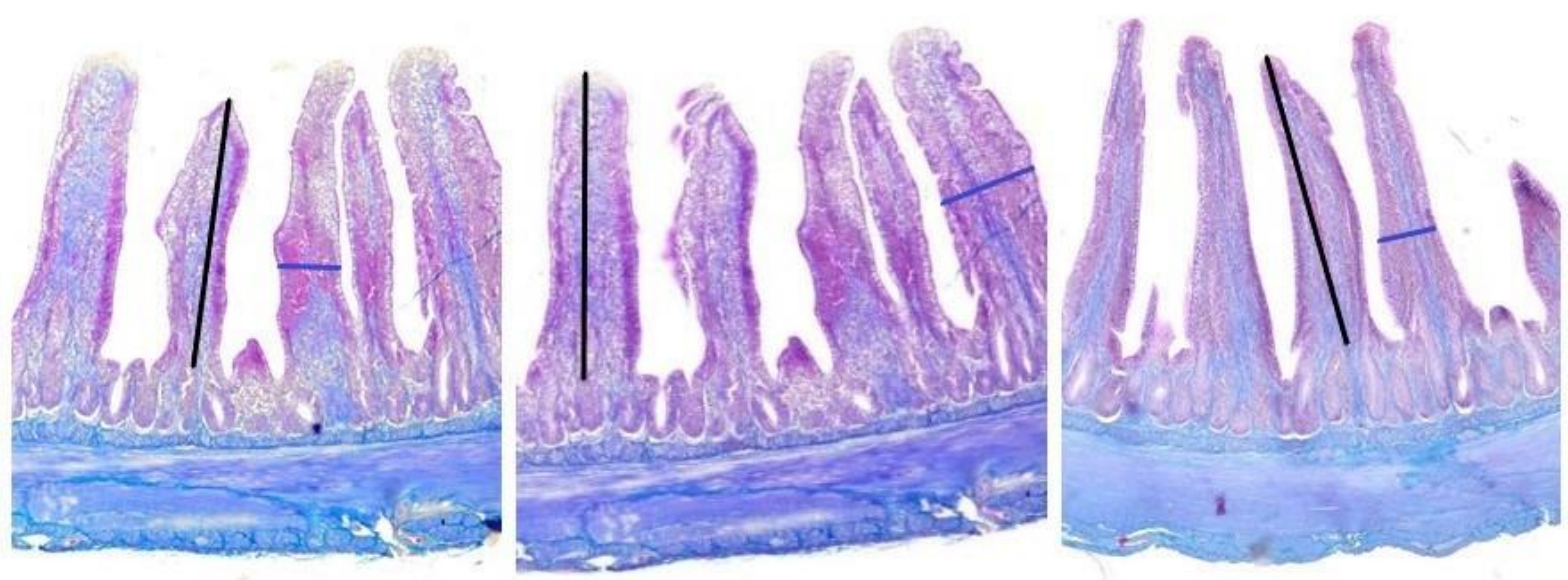

A

$\overline{200 \mu \mathrm{m}} \quad$ B

$\overline{200 \mu \mathrm{m}} \mathrm{C}$

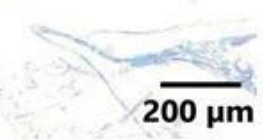

Figure 5: On the 42st day of the study, villus height (black lines) and villus width (blue lines) in the ileums of control (A) and digestrom100 (B) and digestrom150 (C)-treated groups $(\mathrm{n}=8)$. Crossmon triple staining. Scale bar: $200 \mu \mathrm{m}$.

Table 4. On the 42nd day of the study, villus height, villus width, crypt depth, tunica muscularis thickness and the number of goblet cells in the ileums of control and digestrom-treated groups ( $\mathrm{n}=8$ ).

\begin{tabular}{|c|c|c|c|c|c|}
\hline Groups & $\begin{array}{l}\text { Villus Height } \\
\begin{array}{c}(\mu \mathrm{m}) \\
(\mathrm{x} \pm S \mathrm{x})\end{array}\end{array}$ & $\begin{array}{l}\text { Villus Width } \\
\begin{array}{c}(\mu \mathrm{m}) \\
(\bar{x} \pm S \bar{x})\end{array}\end{array}$ & $\begin{array}{l}\text { Crypt Depth } \\
\begin{array}{c}(\mu \mathrm{m}) \\
(\bar{x} \pm S \bar{x})\end{array}\end{array}$ & $\begin{array}{c}\text { Muscular } \\
\text { Thickness } \\
(\mu \mathrm{m}) \\
(\mathrm{x} \pm \mathrm{S} x)\end{array}$ & $\begin{array}{c}\begin{array}{c}\text { Number of } \\
\text { Goblet Cells }\end{array} \\
(\bar{x} \pm S x)\end{array}$ \\
\hline Control & $455.04 \pm 12.68^{\mathrm{b}}$ & $164.85 \pm 4.21^{b}$ & $146.90 \pm 3.79$ & $215.61 \pm 2.46$ & $14.06 \pm 0.14$ \\
\hline DIG100 & $510.36 \pm 14.41 a$ & $197.80 \pm 5.96^{a}$ & $148.03 \pm 4.19$ & $229.06 \pm 5.43$ & $13.57 \pm 0.18$ \\
\hline DIG150 & $535.10 \pm 16.15^{a}$ & $169.55 \pm 3.46^{b}$ & $145.75 \pm 3.02$ & $238.43 \pm 5.96$ & $13.66 \pm 0.16$ \\
\hline $\mathrm{p}$ & $* * *$ & $* * *$ & NS & NS & NS \\
\hline
\end{tabular}




\section{DISCUSSION}

Murugesan et al. (2015) and Namkung et al. (2004) found that supplementation of herbal extract mixture to broiler chicken rations increased villus height in small intestines, Tavangar et al. (2021) reported that it significantly increased both the villus height and the villus width. Thus, in the absence of inflammation in the intestines, it has been shown that increased villus height and villus width increase surface area, digestion and absorption levels, and provide better digestion and absorption. In the study, herbal extract mixture supplementation to broiler chick rations significantly affected villus height, villus width, tunica muscularis thickness and goblet cell counts in duodenum and ileum sections of 21-day-old chicks. In the presented study, duodenal villus height was found to be significantly higher in DIG100 group at the age of 21 days and in DIG150 group at the age of 42 days compared to control groups as similar to the studies of Murugesan et al. (2015), Namkung et al. (2004) and Tavangar et al. (2021). The height of ileum villus was found to be significantly higher in DIG100 and DIG150 groups at the age of 42 days compared to control group. In addition, duodenal villus width was found to be wider in DIG150 group at the age of 42 days compared to control group. It was determined that ileum villus width was significantly wider in DIG100 and DIG150 groups at the age of 21 days, and in DIG100 group at the age of 42 days compared to control group.

Intestinal crypts are the main source of epithelial cells in the structure of the villus intestinalis. Crypt depth is directly related to the epithelial cell cycle (Markovic et al. 2009). Murugesan et al. (2015) determined that the addition of phytogenic feed additives to chicken rations decreased the crypt depth in the jejunum but there was no difference between groups in duodenum and ileum. Humer et al. (2015) also determined that the addition of phytogenic feed additives to male broiler rations did not affect the crypt depth in ileum. The crypt depth findings of our study are consistent with these studies (Humer et al. 2015, Murugesan et al. 2015).

Tunica muscularis thickness shows the microbe load in the intestines of broiler chicks. Broiler chicks with thin tunica muscularis have a lower germ load, which positively reflects to body weight gain (Gordon and Bruckner-Kardoss 1961). Murugesan et al. (2015) determined that the addition of phytogenic feed additives to broiler chicken rations significantly reduced the thickness of the tunica muscularis in the duodenum and ileum. Humer et al. (2015) also determined that the addition of phytogenic feed additives to male broiler rations did not affect the thickness of the tunica muscularis in ileum. In the present study, duodenum tunica muscularis thickness was found to be lower in the DIG100 group compared to control group at the age of 21 days. The thickness of the ileum tunica muscularis was found to be thinner in DIG100 and DIG150 groups at the age of 21 days. Our findings are in line with the study of Murugesan et al. (2015) but are inconsistent with the study of Humer et al. (2015). The reason for this incompatibility may be the type of phytogenic feed additives or the application doses.

The increase in number of goblet cells per villus is associated with high production of mucins and glycoproteins that bind to pathogenic bacteria and prevent them from attaching to the intestinal mucosa (Chacher et al. 2017). Namkung et al. (2004) and Humer et al. (2015) found that herbal extract mixture supplement to broiler chicken rations did not affect the number of goblet cells in the small intestine. In the present study, herbal extract mixture supplementation to broiler chick rations did not affect goblet cell counts in the duodenum at the age of 21 days and in the ileum at the age of 42 days in accordance with these studies.

But, it was determined that the number of goblet cells in the duodenum decreased in DIG100 and DIG150 groups in the 42-day age compared to control group, and the number of goblet cells in ileum increased in DIG150 group in the 21-day age. Unlike other studies (Namkung et al. 2004) and Humer et al. 2015), the decrease in the number of goblet cells in duodenum and the increase in ileum may be due to the type or application doses of the phytogenic feed additives.

\section{CONCLUSIONS}

In conclusion, in the presented study, it was determined that herbal extract mixture supplementation to broiler chick rations generally increased villus height and villus width, and decreased tunica muscularis thickness. Therefore, herbal extract mixture might lead to better digestion and absorption by increasing the intestinal surface area, digestion and absorption levels, also increase body weight gain in broiler chicks by reducing the microbial load.

Conflict of Interest: The authors declare that they have no conflict of interest.

Ethical Permission: Ethics committee report of the study was obtained from Aydin Adnan Menderes University Animal Experiments Local Ethics Committee with the number of 64583101/2021/094 dated June 24, 2021.

\section{REFERENCES}

Adam JN, Asgarali Z, Singh SM, Ezeokoli CD. A Serological Agostini PS, Sola-Oriol D, Nofrarias M, Barroeta AC, Gasa J, Manzanilla EG. Role of in-feed clove supplementation on growth performance, intestinal microbiology, and morphology in broiler chicken. Livest Sci. 2012; 147:113-118.

Aviagen. Ross 308 broiler: nutrition specifications. 2014. p.1-10. Available from: http://eu.aviagen.com/assets/Tech_Center/Ross_Broile 
r/Ross-308-Broiler-Nutrition-Specs-plant-2014-EN.pdf. Accessien date: 02.01.2016.

Alçiçek A, Bozkurt M, Çabuk M. The effect of a mixture of herbal essential oils, an organic acid or a probiotic on broiler performance. S Afr J Anim Sci. 2004; 34(4):217222.

Basmacioğlu H, Tokuşoğlu Ö, Ergül M. The effect of oregano and rosemary essential oils or alpha-tocopheryl acetate on performance and lipid oxidation of meat enriched with n-3 PUFA's in broilers. S Afr J Anim Sci. 2004; 34 (3):197-210.

Chacher MFA, Kamran Z, Ahsan U, Ahmad S, Koutoulis KC, Qutab Ud Din HG, Cengiz O. Use of mannan oligosaccharide in broiler diets:an overview of underlying mechanisms. Worlds Poult Sci J. 2017; 73:831-844.

Cherian G, Orr A, Burke I.C, Pan W. Feeding Artemisia annua alters digesta $\mathrm{pH}$ and muscle lipid oxidation products in broiler chickens. Poult Sci. 2013; 92 (4):1085-1090.

Conover WJ. Practical Nonparametric Statistics. New York: John Wiley \& Sons, 1980; pp. 229-239.

Crossmon GA. A modification of Mallory's connective tissue stain with a discussion of the principles involved. Anat Rec. 1937; 69(1):33-38.

Culling CFA, Allison RT, Barr WT. Cellular pathology technique. Butterworths and Co Ltd London, 1985.

Çetin M. Göçmen M. Kanatlı hayvanların beslenmesinde antibiyotiklere alternatif olarak kekik (thyme) kullanmanın etkileri. HR Ü Z F Derg. 2013; 17(3):35-40.

Du, E, Wang W, Gan L, Li Z, Guo S, Guo Y. Effects of thymol and carvacrol supplementation on intestinal integrity and immune responses of broiler chickens challenged with Clostridium perfringens. J Anim Sci Biotechnol. 2016; 7:19.

Du A, Hu S. Effects of a herbal complex against Eimeria tenella infection in Chickens. J Vet Med. 2004; 51:194-197.

Erhan MK. Kanatlı seslemesinde antibiyotiklere alternatif olarak kullanılan bitki ekstraktlarının performans değerleri ve diğer bazı parametreler açısından değerlendirilmesi. Alinteri Zir Bil Derg. 2015; 28(1):45-54.

Gordon HA, Bruckner-Kardoss E. Effect of normal microflora on intestinal surface area. Am J Physiol. 1961; 201:175178.

Guynot ME, Marín S, Set ÚL, Sanchis V, Ramos AJ. Screening for antifungal activity of some essential oils against common spoilage fungi of bakery products. Food Sci Technol Int. 2005; 11(1):25-32.

Hafeez A, Männer K, Schieder C, Zentek J. Effect of supplementation of phytogenic feed additives (powdered vs. encapsulated) on performance and nutrient digestibility in broiler chickens. Poult Sci. 2016; 95(3):622629.

Hong JC, Steiner T, Aufy A, Lien TF. Effects of supplemental essential oil on growth performance, lipid metabolites and immunity, intestinal characteristics, microbiota and carcass traits in broilers. Livest Sci. 2012; 144 (3):253-262.

Humer E, Rohrer E, Windisch W, Wetscherek W, Schwarz C, Jungbauer L, Schedle KJ. Gender-specific effects of a phytogenic feed additive on performance, intestinal physiology and morphology in broiler chickens. Anim Physiol Anim Nutr. 2015: 99(4):788-800.

Junqueira LC, Carneiro J, Abrahamsohn PA, Dos Santos MF, Zorn TMT. Temel histoloji. In: Aytekin Y, Solakoğlu S. (Eds). İstanbul: Nobel Matbaacıllk, 2006; pp. 431-447.

Lee KW, Everts H, Kappert HJ, Frehner M, Losa R, Beynen AC. Effects of dietary essential oil components on growth performance, digestive enzymes and lipid metabolism in female broiler chickens, Br Poult Sci. 2003; 44(3):450-457.

Markovic R, Sefer D, Krstic M, Petrujkic B. The effect of different growth promotors on broiler performance and gut morphology. Arch Med Vet. 2009; 41:163-169.

Mountzouris KC, Paraskevas V, Tsirtsikos P, Palamidi I, Steiner T, Schatzmayr G, Fegeros K. Assessment of a phytogenic feed additive effect on broiler growth performance, nutrient digestibility and caecal microflora composition. Anim Feed Sci Technol. 2011; 168:(34):223-231.

Murugesan GR, Syed B, Haldar S, Pender C. Phytogenic feed additives as an alternative to antibiotic growth promoters in broiler chickens. Front Vet Sci. 2015; 2:21.

Namkung H, Li M, Gong J, Yu H, Cottrill M, de Lange CFM. Impact of feding blends of organic acids and herbal extracts on growth performance, gut microbiota and digestive function in newly weaned pigs. Can J Anim Sci. 2004; 84:697-704.

Peng QY, Li JD, Li Z, Duan ZY, Wu YP. Effects of dietary supplementation with oregano essential oil on growth performance, carcass traits and jejunal morphology in broiler chickens. Anim Feed Sci Technol. 2016; 214:148153.

Tanyolaç A. Özel Histoloji. 3. baskı. Ankara: Yorum Basın Yay1n, 1999; pp. 132-143.

Tavangar P, Gharahveysi S, Rezaeipour V, Irani M. Efficacy of phytobiotic and toxin binder feed additives individually or in combination on the growth performance, blood biochemical parameters, intestinal morphology, and microbial population in broiler chickens exposed to aflatoxin B(1). Trop Anim Health Prod. 2021; 53(3):335.

Upadhaya SD, Kim IH. Efficacy of phytogenic feed additive on performance, production and health status of monogastric animals -a review. Ann Anim Sci. 2017; 17(4):929-948.

Vesna T, Lazarević M, Sinovec Z, Tokić A. The influence of different feed additives to performances and immune response in broiler chicken. Acta Vet. 2007; 57:217-229.

Yörük MA, Gül M, Hayırlı A, Macit M. The Effects of Supplementation of Humate and Probiotic on Egg Production and Quality Parameters During Late Laying Period in Hens. Poult Sci. 2004; 83:84-88.

Zeng Z, Zhang S, Wang H, Piao X. Essential oil and aromatic plants as feed additives in non-ruminant nutrition: a review. J Anim Sci Biotechnol. 2015; 6:7. 